\title{
Cyanides and their Attenuation in wastewaters using green chemistry.
}

by Andrews Quashie

\begin{abstract}
Cyanides, though naturally occurring, are environmental pollutants when not treated properly. Some methods used to attenuate cyanides in waste waters from industrial processes are based simply on changing the physico-chemical properties of the waste water such as the $\mathrm{pH}$ and temperature. The effectiveness of these methods are based on hydrolysis of the cyanide and volatilization of the hydrogen cyanide formed. Another reaction which takes place simultaneously is ultraviolet-catalysed oxidation which converts the cyanide to bicarbonates and carbonates.
\end{abstract}

The changes in the cyanide degradation rate approaches a minimum faster if the cyanide solution is maintained at a higher than ambient constant temperature.

Keywords: cyanide attenuation, waste water, light irradiation, green chemistry

Corresponding author: Andrews Quashie

Email: andy.quash@gmail.com, andrews q@yahoo.com

Organisation: Institute of Industrial Research, C. S. I. R., Ghana

ORCID ID: 0000-0003-3949-0927 


\section{Introduction}

The term cyanide is used to refer to a wide array of cyanide containing chemicals. A cyanide is any chemical compound that contains the monovalent combining group $\mathrm{CN}$. This group, known as the cyano group, consists of a carbon atom triple bonded to a nitrogen atom ${ }^{1}$.

\section{Occurrence}

Cyanides are produced by certain bacteria, fungi, and algae and are found in a number of plants. Cyanides are found in substantial amounts in certain seeds and fruit stones, e.g., those of apricots, apples, and peaches ${ }^{2}$. In plants, cyanides are usually bound to sugar molecules in the form of cyanogenic glycosides and defend the plant against herbivores. Cassava roots (also called manioc), an important potato - like food grown in tropical countries (and the base from which tapioca is made), also contain cyanogenic glycosides. ${ }^{3}, 4$. A few species of centipedes, millipedes, insects, beetles, moths and butterflies secrete cyanide for defensive purposes in repelling predators such as toads and birds ${ }^{5}$.

The cyanide radical $\mathrm{CN}$. has been identified in interstellar space ${ }^{6}$. The cyanide radical (called cyanogen) is used to measure the temperature of interstellar gas clouds ${ }^{7}$.

Production

Cyanide is manufactured from ammonia and natural gas, and is a by-product of the manufacture of acrylic fibres and plastics.

Types of cyanide

Cyanide can occur in many forms. It can exist as a free ion or can combine with many different elements. Table 1 below gives the various categories of cyanides.

Table 1: Different types of cyanide and their description

\begin{tabular}{|c|c|c|}
\hline Term & Description & Example \\
\hline Cyanide ion & the free cyanide ion & $\mathrm{CN}^{-}$ \\
\hline Molecular HCN & $\begin{array}{l}\text { hydrogen cyanide or } \\
\text { hydrocyanic acid }\end{array}$ & $\mathrm{HCN}$ \\
\hline Free Cyanide & $\begin{array}{l}\text { includes the cyanide ion and } \\
\text { hydrogen cyanide }\end{array}$ & $\mathrm{CN}^{-}, \mathrm{HCN}$ \\
\hline $\begin{array}{l}\text { Simple Cyanide } \\
\text { (a) Readily Soluble }\end{array}$ & $\begin{array}{l}\text { a salt which dissociates to } \\
\text { form a cyanide ion }\end{array}$ & \\
\hline
\end{tabular}




\begin{tabular}{|c|c|c|}
\hline Term & Description & Example \\
\hline $\begin{array}{l}\text { (b) Neutral Insoluble } \\
\text { Salts }\end{array}$ & & $\begin{array}{c}\mathrm{NaCN} \mathrm{NaCN}, \mathrm{KCN}, \\
\mathrm{Ca}(\mathrm{CN}) 2, \mathrm{Hg}(\mathrm{CN}) 2, \\
\mathrm{Zn}(\mathrm{CN}) 2, \mathrm{Cd}(\mathrm{CN}) 2, \mathrm{CuCN}, \\
\mathrm{Ni}(\mathrm{CN}) 2, \mathrm{AgCN}\end{array}$ \\
\hline Complex cyanide & $\begin{array}{l}\text { easily dissociates to form } \\
\text { another cyanide compound }\end{array}$ & $\mathrm{Au}(\mathrm{CN})_{2}$ \\
\hline WAD $^{1}$ cyanide & $\begin{array}{l}\text { cyanide that is readily } \\
\text { released from cyanide } \\
\text { containing compounds when } \\
\text { the } \mathrm{pH} \text { is lowered }\end{array}$ & $\begin{array}{l}\mathrm{Cd}(\mathrm{CN})_{2}, \mathrm{Zn}(\mathrm{CN})_{4}^{-2} \\
\mathrm{Cd}(\mathrm{CN})_{3}^{-1}, \mathrm{Cd}(\mathrm{CN})_{4}^{-2}\end{array}$ \\
\hline $\begin{array}{l}\text { Moderately Strong } \\
\text { Metal-Cyanide } \\
\text { Complexes }\end{array}$ & $\begin{array}{l}\text { dissociates to form another } \\
\text { cyanide compound }\end{array}$ & $\begin{array}{l}\mathrm{Cu}(\mathrm{CN})_{2}{ }^{-1}, \mathrm{Cu}(\mathrm{CN})_{3}{ }^{-2}, \\
\mathrm{Ni}(\mathrm{CN})_{4}^{-2}, \mathrm{Ag}(\mathrm{CN})_{2}{ }^{-2}\end{array}$ \\
\hline$S A D^{2}$ cyanide & $\begin{array}{l}\text { cyanide that is released from } \\
\text { cyanide containing } \\
\text { compounds under highly } \\
\text { acidic conditions }\end{array}$ & $\begin{array}{l}\mathrm{Co}(\mathrm{CN})_{6}^{+}, \mathrm{Fe}(\mathrm{CN})_{6}^{-3}, \\
\mathrm{Fe}(\mathrm{CN})_{6}^{-4}, \mathrm{Co}(\mathrm{CN})_{6}^{-4}, \\
\mathrm{Au}(\mathrm{CN})_{2}^{-1}, \mathrm{Hg}(\mathrm{CN})_{4}^{2-}\end{array}$ \\
\hline Total cyanide & $\begin{array}{l}\text { the sum of all of the different } \\
\text { forms of cyanide present in a } \\
\text { system }\end{array}$ & \\
\hline
\end{tabular}

Uses

Cyanide compounds have many useful purposes. Cyanide has been used in synthetic dyes since the 1850 s and it is what makes the fabric used to produce blue-jeans blue ${ }^{5}$.

Cyanide is also used in the manufacture of nylon, plastic glass, perfume, soaps, fertilizers, paints, animal food supplements, and pharmaceuticals, including heart medication and medical test kits. Cyanide compounds are used in surgical dressings that promote healing and reduce scarring, in anti-cancer preparations, and in drugs to reduce high-blood pressure ${ }^{5}, 1$.

\footnotetext{
${ }^{1}$ weak acid dissociable cyanide

${ }^{2}$ strong-acid dissociable cyanide
} 
Due to the high stability of their complexation with iron, ferrocyanides (Sodium ferrocyanide E535, Potassium ferrocyanide E536, and Calcium ferrocyanide E538) ${ }^{8}$ do not decompose to lethal levels in the human body and are used in the food industry as, e.g., an anticaking agent in table salt ${ }^{9}$.

Cyanide is used in electroplating where it 'plates' one type of metal onto another. Examples are silver and gold plated dinnerware and jewellery, and brass plated bathroom fixtures ${ }^{5}$.

Due to its toxic nature, it has been used as a fumigant and poison since early times. Cyanide has been used to kill people in judicial executions, genocide, and mass suicide, and has been used as a chemical warfare agent ${ }^{5}, 1$.

\section{Destruction/Removal of Cyanides}

The small amounts of cyanide entering our bodies from our daily intake of the above foods, is removed by the liver to prevent harmful levels building up in our systems ${ }^{5}$.

There are several methods to destroy, degrade and detoxify cyanide in the environment which involve physical, biological and chemical processes.

\section{Environmental impacts of Cyanide}

Cyanide has low persistence in the environment and is not accumulated or stored in any mammals that have been studied.

Cyanide biomagnification in food webs has not been reported possibly due to rapid detoxification at sub-lethal doses, and death at higher doses. Low levels of cyanide may be harmless under seasonal or other variations that allow organisms to recover and detoxify.

Cyanide is seldom persistent in surface waters and soils due to complexion or sedimentation, microbial metabolism and loss from volatilization, but may persist in groundwater for extended periods of time.

Long term adverse effects associated with mining sites are related primarily to metals rather than cyanide. Cyanide can naturally degrade rapidly in the environment by volatilizing to hydrogen cyanide gas ( $\mathrm{HCN}$ ) 
Cyanide can mix with air and water to produce ammonia and bicarbonate. Ammonia can be toxic in the aquatic system, but is an important component of the nitrogen cycle, vital for plant growth.

Consequently, low concentrations of ammonia are rapidly assimilated. Cyanide is toxic to most species in varying amounts.

Aquatic organisms are very sensitive to cyanide. Fish have been shown to be the most sensitive aquatic organism, followed by invertebrates. Algae and aquatic plants have been shown to be comparatively tolerant to cyanide. Low concentrations can sometimes enhance germination and growth. Elevated concentrations inhibit respiration and can lead to death ${ }^{5}$.

Birds seem to have varying sensitivity to cyanide. They may absorb cyanide through their skin when wading or swimming, or ingest it through drinking.

Water and Wastewater Quality

In Ghana, the discharge limits are $1.0 \mathrm{mg} / \mathrm{L}$ of total cyanide, $0.6 \mathrm{mg} / \mathrm{L}$ of WAD cyanide and $0.2 \mathrm{mg} / \mathrm{L}$ for free cyanide ${ }^{10}$. 


\section{Experimental}

Factors affecting natural attenuation of Cyanides in the environment Dodge and Zabbon ${ }^{11}$ and Chester Engineers ${ }^{12}$ identified $\mathrm{pH}$, temperature, interfacial surface area, pressure, concentration and degree of agitation as factors affecting cyanide volatilisation. Palaty and Horokova-Jakubu ${ }^{13}$ cited in Simovic et al. ${ }^{14}$ also studied volatilisation of cyanide from simple cyanide solutions. They identified the same variables that affected cyanide volatilisation as Dodge and Zabbon $^{11}$. They also determined solution depth to be an important variable.

Simovic et a $\left.\right|^{14}$. and Zaidi et $\mathrm{a}^{15}$ have also attempted to quantify cyanide losses in process ponds.

This study is therefore to determine how $\mathrm{pH}$ and temperature influence the rate of attenuation of free cyanide in solution by simulating a cyanide-containing wastewater in the laboratory.

The experiments were designed to investigate how $\mathrm{pH}$, temperature and light irradiation affect the degradation process of cyanide in water.

Preparation of Solutions

Solutions of sodium cyanide ( $\mathrm{NaCN}$ ) were prepared and exposed to the following conditions

- 60 Watt incandescent bulb

- 100 Watt incandescent bulb

- Sunlight outside the laboratory

- Dark room (D.R.)

The rate and level of cyanide degradation together with the corresponding $\mathrm{pH}$ and temperature were monitored.

Equipment Used

The main equipment used was the Cyberscan $\mathrm{pH}$ meter which is equipped with a temperature probe.

The incandescent bulbs were suspended $16 \mathrm{~cm}$ above the beakers containing the cyanide solutions and placed in a fume chamber. 
The dark room was a cupboard with a door which excludes all light when shut. Light Irradiation effect on Temperature and $\mathrm{pH}$ A mass of $0.027 \mathrm{~g}$ of $\mathrm{NaCN}$ was dissolved in $1000 \mathrm{~cm}^{3}$ of distilled water. $200 \mathrm{~cm}^{3}$ each of this solution were put in three separate $500 \mathrm{ml}$ glass beakers. Two of the beakers and their content were exposed to a $60 \mathrm{~W}$ incandescent bulb and a 100 $W$ incandescent bulb respectively. The third beaker and contents was kept in a dark room.

The temperature and $\mathrm{pH}$ of the cyanide solutions were then monitored daily for four days. The results are shown in Figures 2 and 3.

Light Irradiation effect on Cyanide Degradation A mass of $0.135 \mathrm{~g}$ of $\mathrm{NaCN}$ were dissolved in $5000 \mathrm{~cm}^{3}$ distilled water. The solution was then divided equally into three parts. Two of these were exposed to a $60 \mathrm{~W}$ incandescent bulb and a $100 \mathrm{~W}$ incandescent bulb respectively. The third part was kept in a dark room. The concentration of free cyanide was monitored over 24 hours. The results are shown on Figure 4.

Solar radiation effect on Carbonate degradation and Bicarbonate Formation A mass of $0.054 \mathrm{~g}$ of $\mathrm{NaCN}$ were dissolved in $2000 \mathrm{~cm} 3$ of distilled water and the solution divided equally into two portions. One portion was placed in the Dark-

room while the other was placed in the open where it was exposed to sunlight for four days. The concentration of carbonate and bicarbonate were monitored daily for the period. Figure 5 shows the $\mathrm{pH}$ and the level of carbonate and bicarbonate in the solutions.

Influence of Solar radiation on Cyanide Degradation

$0.054 \mathrm{gm}$ of $\mathrm{NaCN}$ were dissolved in $2000 \mathrm{~cm} 3$ of distilled water. The solution was then divided into two portions. One portion was exposed to sunlight with the other portion kept in the dark room. The $\mathrm{pH}$ and the level of free cyanide were monitored daily for four days. Figure 6 shows the results of the level of cyanide in both solutions. 


\section{DISCUSSIONS OF RESULTS}

The temperature of the solutions when exposed to the light bulbs increased with time to a high of about $40^{\circ} \mathrm{C}$, while the temperature of the solution in the dark room remained relatively stable at about $30^{\circ} \mathrm{C}$ (Figure 2 ).

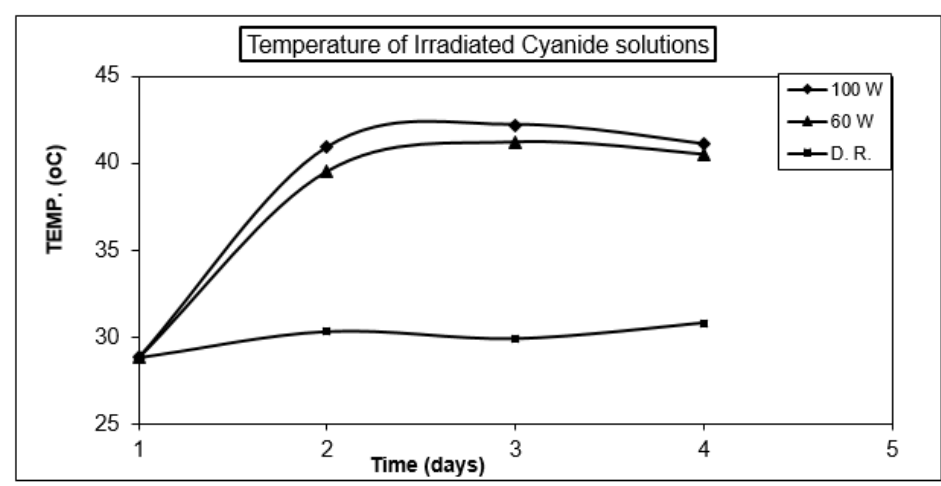

Figure 2: Temperature of Free Cyanide Solutions on Irradiation with Incandescent Bulbs

The $\mathrm{pH}$ of all solutions decreased with time. The $\mathrm{pH}$ of the solutions exposed to the $60 \mathrm{~W}$ and $100 \mathrm{~W}$ bulbs decreased initially and started increasing only after the third day (Figure 3), indicating that some chemical reactions might be taking place during the period of exposure.

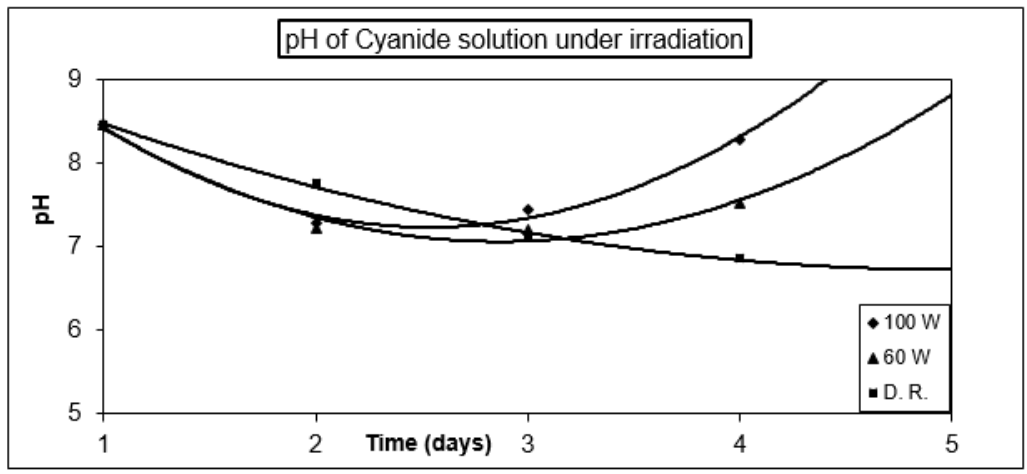

Figure 3: pH of Free Cyanide Solutions on Irradiation with Incandescent Bulbs

This phenomenon could be explained by a close look at the reactions that may take place.

Two types of reaction could be proposed for the loss of cyanide in this study ${ }^{16}$. One of the reactions is hydrolysis as presented in equations 2.0 and 3.0 which occur very slowly at ambient temperatures ${ }^{17}$.

At $\mathrm{pH}$ less than 6,

$\mathrm{CN}^{-}+\mathrm{H}_{2} \mathrm{O} \rightarrow \mathrm{HCN}+\mathrm{OH}^{-}$

At $\mathrm{pH}$ greater than 10 ,

$\mathrm{CN}^{-}+2 \mathrm{H}_{2} \mathrm{O} \rightarrow \mathrm{NH}_{3}+\mathrm{HCO}_{3}^{-}$ 3.0 
The other reaction is oxidation as given in equations 4.0 and 5.0.

$$
4 \mathrm{OH}^{-}+2 \mathrm{CN}^{-} \rightarrow 2 \mathrm{CNO}^{-}+2 \mathrm{H}_{2} \mathrm{O}+4 \mathrm{e}^{-}
$$

The cyanate ion produced can also decompose slowly to

$$
\begin{aligned}
& \mathrm{CNO}^{-}+\mathrm{H}_{2} \mathrm{O}+\mathrm{H}^{+} \rightarrow \mathrm{NH}_{4}^{+}+\mathrm{HCO}_{3}^{-} \\
& \quad \text { and } \\
& \mathrm{CNO}^{-}+\mathrm{NH}_{4}^{+} \rightarrow \mathrm{CO}\left(\mathrm{NH}_{2}\right)_{2} \text { (urea) ........ }
\end{aligned}
$$

$$
2 \mathrm{NaCN}+\mathrm{O}_{2}+\text { catalyst } \rightarrow 2 \mathrm{NaCNO} \text {. }
$$

Furthermore, the $\mathrm{CO}_{2}$ in the atmosphere may also dissolve in the solutions according to the following reactions:

$$
\begin{aligned}
& \mathrm{CO}_{2}+\mathrm{H}_{2} \mathrm{O} \rightarrow \mathrm{H}_{2} \mathrm{CO}_{3} \rightarrow \mathrm{H}^{+}+\mathrm{HCO}_{3}^{-} \\
& \mathrm{H}_{2} \mathrm{CO}_{3}+2 \mathrm{OH}^{-} \rightarrow \mathrm{CO}_{3}^{2-}+2 \mathrm{H}_{2} \mathrm{O}(\mathrm{I})
\end{aligned}
$$

which will also change the $\mathrm{pH}$ of the solutions. Consequently, the $\mathrm{pHs}$ of the solutions were found to decrease with time.

At this reduced $\mathrm{pH}$, the cyanide hydrolyses to $\mathrm{HCN}$ which volatilises. The oxidation mechanism is slower and may not contribute much to the attenuation at this stage.

This is confirmed by Simovic et al ${ }^{14}$ who found out that ninety percent of the free cyanide was removed by hydrolysis and volatilization of $\mathrm{HCN}$ and an additional ten percent was removed by chemical oxidation ${ }^{18}$ in surface waters of process ponds in mines.

With the exposure of the cyanide solution to sunlight, the oxidative reaction seemed to enhance the loss of cyanide from solution. It seemed the cyanate ion might have decomposed slowly to give the ammonium and bicarbonate ions as shown in equations 4.1 and 6.0. 
At $\mathrm{pH}$ less than 9.36, the $\mathrm{pH}$ at which all the monitoring took place, the predominant form of cyanide is $\mathrm{HCN}$. This volatizes, leaving excess $\mathrm{OH}^{-}$ions according to the following equation

$$
\mathrm{CN}^{-}+\mathrm{H}_{2} \mathrm{O} \rightarrow \mathrm{HCN}(\mathrm{g})+\mathrm{OH}^{-}\left(\mathrm{K}_{\text {diss }}=2.5 \times 10^{9}\right)
$$

Simultaneously, atmospheric $\mathrm{CO}_{2}$ is absorbed into the solution as follows

$$
\mathrm{CO}_{2}+\mathrm{H}_{2} \mathrm{O} \rightarrow \mathrm{H}^{+}+\mathrm{HCO}_{3}^{-} \quad\left(\mathrm{K}_{\text {diss }}=4.2 \times 10^{-7}\right) \text {. }
$$

The $\mathrm{OH}^{-}$from (equ. 7) reacts with the carbonic acid $\mathrm{H}_{2} \mathrm{CO}_{3}$ as follows

$$
\mathrm{H}_{2} \mathrm{CO}_{3}+2 \mathrm{OH}^{-} \rightarrow \mathrm{CO}_{3}^{2-}+2 \mathrm{H}_{2} \mathrm{O}
$$

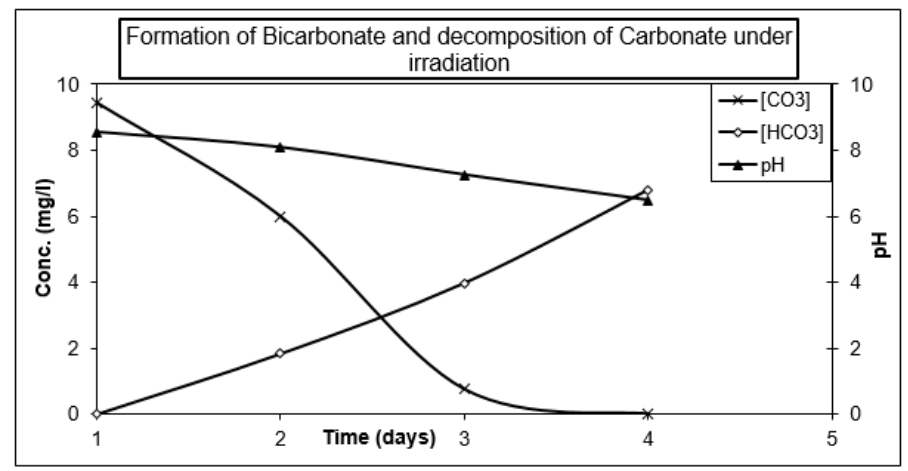

Figure 4: Formation of Bicarbonate and decomposition of Carbonate during irradiation of cyanide solution

This causes a decrease in the $\mathrm{pH}$ of the solution.

The $\mathrm{CO}_{3}{ }^{2-}$ (in equation 9.0) reacts with the $\mathrm{CO}_{2}$ from the atmosphere

$$
\mathrm{CO}_{2}+\mathrm{CO}_{3}^{2-}+\mathrm{H}_{2} \mathrm{O} \rightarrow 2 \mathrm{HCO}_{3}^{-}\left(\mathrm{K}_{\text {diss }}=2.08 \times 10^{10}\right) \text {. }
$$

This explains the increase in the level of bicarbonate shown in Figure 4 below, implying that most of the cyanide in the sample exposed to sunlight degraded through the hydrolysis reaction.

The slower oxidative reactions which convert $\mathrm{CN}^{-}$to $\mathrm{CNO}^{-}$and $\mathrm{HCN}$ to $\mathrm{HCNO}$ may also take place with the sunlight being the catalyst as follows

$$
\mathrm{CN}^{-}+\mathrm{O}_{2}+\text { Sunlight (catalyst) } \rightarrow \mathrm{CNO}^{-}
$$

The $\mathrm{CNO}^{-}$also hydrolyses to give bicarbonates

$$
\begin{aligned}
& \mathrm{CNO}^{-}+\mathrm{H}_{2} \mathrm{O}+\mathrm{H}^{+}=\mathrm{NH}_{4}^{+}+\mathrm{HCO}_{3}^{-} \\
& 2 \mathrm{HCN}+\mathrm{O}_{2} \rightarrow 2 \mathrm{HCNO}
\end{aligned}
$$


The $\mathrm{CN}^{-}$also hydrolyses to give ammonia and bicarbonates

$$
\mathrm{CN}^{-}+2 \mathrm{H}_{2} \mathrm{O} \rightarrow \mathrm{NH}_{3}+\mathrm{HCO}_{3}^{-}
$$

The ammonia is converted to $\mathrm{NH}_{4}{ }^{+}$in solution

$$
\mathrm{NH}_{3}+\mathrm{H}^{+}=\mathrm{NH}_{4}^{+}
$$

In effect, the concentrations of $\mathrm{CN}^{-}$and $\mathrm{CO}_{3}{ }^{2-}$ will decrease while that of $\mathrm{HCO}_{3}{ }^{-}$will increase as confirmed by Figure 5 .

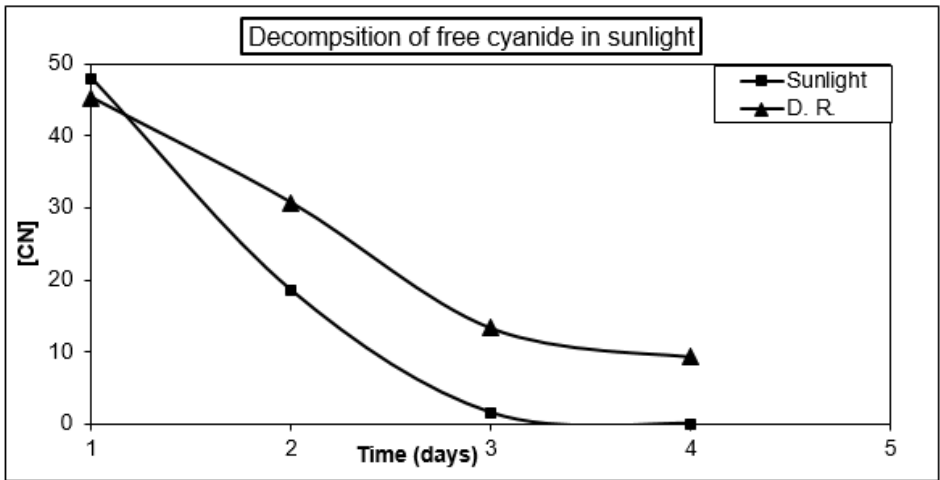

Figure 5: Decomposition of Free Cyanide during exposure to Sunlight

This supports Miles ${ }^{19}$ theory that the ultraviolet light acts as a catalyst to convert dissolved oxygen in solution to ozone, (see figure 5 ) which promptly reacts with the cyanide to cyanate as confirmed by the work of Frank and Bard ${ }^{20}$.

\section{Rate of Degradation}

The rate of degradation is not constant as shown in figure 6 below, indicating there are more than one parameter influencing it. This can be explained by the fact that though both hydrolysis (a chemical reaction) and volatilization are enhanced by high temperature, the individual contributing effects vary depending on the conditions. 


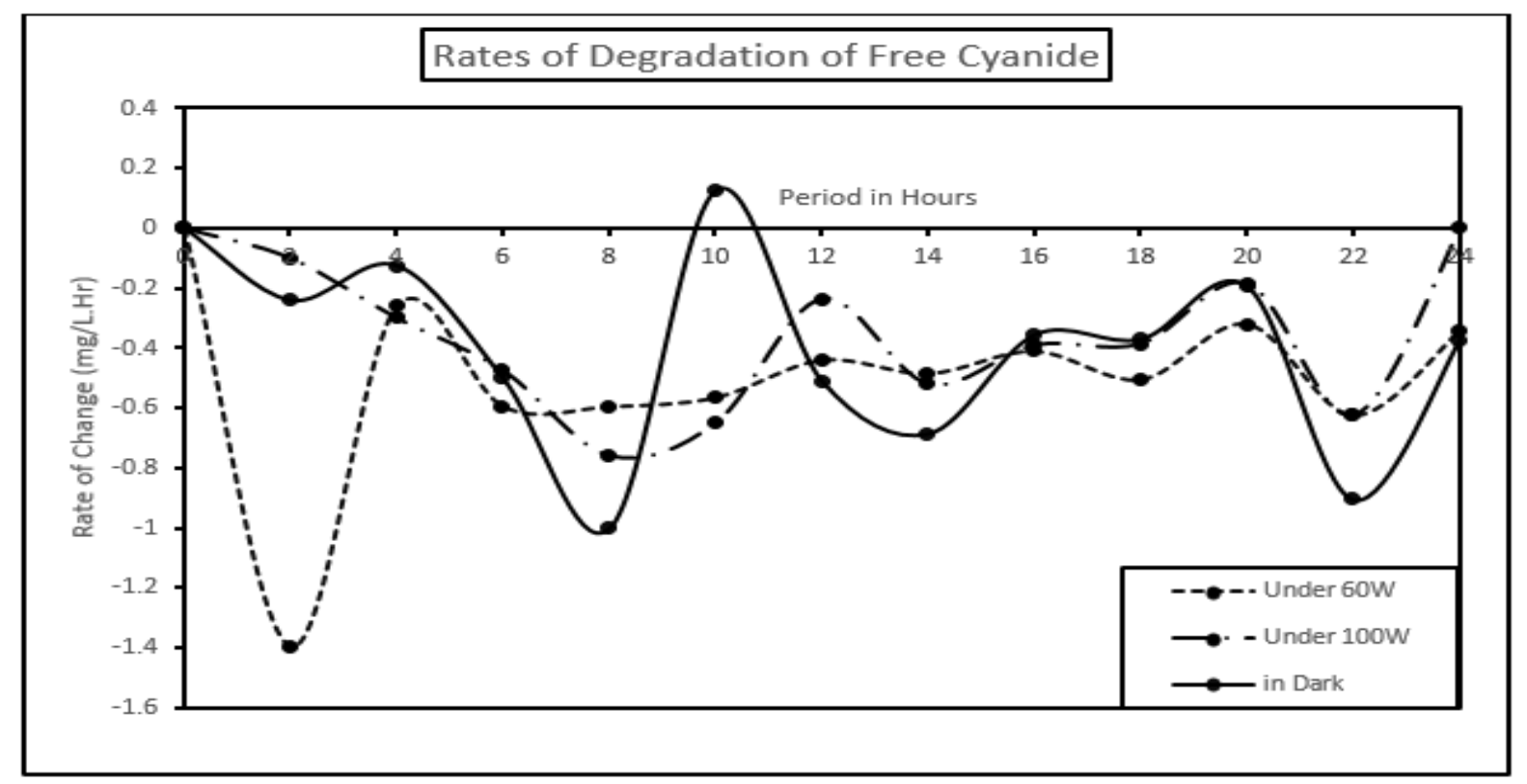

Figure 6: Rates of Degradation of Free Cyanide in solution

The data in study indicates that under constant temperature as created by the $100 \mathrm{~W}$ and $60 \mathrm{~W}$ lamps, unlike under ambient conditions, the rates of degradation will attenuate to a constant figure with time. 


\section{CONCLUSIONS}

It was found in this study that the exposure of cyanide wastewater to sunlight enhanced the attenuation process of free cyanide. The temperature has some influence on the decomposition.

If the cyanide solution is maintained at a constant temperature, the changes in the rate of degradation will gradually decrease to a minimum.

The $\mathrm{pH}$ of the cyanide solution was found to reduce from 8.5 to 7.2 within 3 days. This situation enhanced the hydrolysis of the cyanide, leading to a reduction in the levels of free cyanide in solution.

The main by-product of this attenuation is bicarbonate which is not as harmful as cyanide. 


\section{Acknowledgement}

We wish to acknowledge the assistance provided by Prof Elias Asiam of the University of Mines and Environment, Tarkwa in the initial stages of the study and assistance in assessing the environmental impact of mining wastewaters containing cyanide. 


\section{References}

1. Wikipedia contributors. Cyanide. In: Vol Wikipedia, The Free Encyclopedia; 2015. https://en.wikipedia.org/wiki/Cyanide.

2. Agency for Toxic Substances and Disease Registry. ToxFAQs for Cyanide. 2006. http://www.atsdr.cdc.gov/toxfaqs/tf.asp?id=71\&tid=19. Accessed November 11, 2015.

3. Vetter J. Plant cyanogenic glycosides. Toxicon. 2000;38(1):11-36. doi:10.1016/S00410101(99)00128-2.

4. Jones DA. Why are so many food plants cyanogenic? Phytochemistry. 1998;47(2):155-162. doi:10.1016/S0031-9422(97)00425-1.

5. Laberge Environmental Services. Cyanide - The Facts.; 2001. http://www.geology.gov.yk.ca/pdf/mperg_2001_2.pdf.

6. Pieniazek PA, Bradforth SE, Krylov Al. Spectroscopy of the Cyano Radical in an Aqueous Environment. J Phys Chem A. 110(14):4854-4865. doi:10.1021/jp0545952.

7. Roth KC, Meyer DM, Hawkins I. Interstellar Cyanogen and the temperature of the Cosmic Microwave background radiation. Astrophys J. 413:L67-L71. http://articles.adsabs.harvard.edu/cgi-bin/nphiarticle_query?1993ApJ...413L..67R\&data_type=PDF_HIGH\&whole_paper=YES\&type=PRINTER\&fi letype=.pdf.

8. Bender DA, Bender AE. Benders' Dictionary of Nutrition and Food Technology. Vol illustrate. CRC Press; 1999.

9. Schulz HD. Geochemical Processes in Soil and Groundwater. Vol illustrate. (Schulz HD, Hadeler A, eds.). Wiley; 2003.

10. Environmental Protection Agency G. Environmental Quality Standards--Mining Sector. http://www.epaghanaakoben.org/Content/uploads/Standards_Mining_1.pdf.

11. Dodge BF, Zabbon W. Disposal of Plating Room Wastes IV. Batch Volatilization of Hydrogen Cyanide from Aqueous Solutions of Cyanides. Plating. 1952:39. 
12. Chester Engineers. Report on the Lower Monongahela River Study - Water Quality Conditions, Point and Nonpoint Source Waste Loads Allocations. Coraopolis, Pennsylvania; 1977.

13. Palaty J, Horokova-Jakubu M. The Course and Rate of Removal of Cyanides from Water Under Natural Conditions. Prague, Czech; 1959.

14. Simovic L, Snodgrass W, Murphy K, Schmidt J. Development of a Model to Describe the Natural Attenuation of Cyanide in Gold Mill Effluents. Cyanide Environ. 1985;2:413-432.

15. Zaidi A, Schmidt JW, Simovic L, Scott J. The Art and Science of Treating Wastewaters from Gold Mines. In: Annual Operator's Conference. Vol

16. Dzombak DA, Ghosh RS, Young TC. Physical-Chemical Properties and Reactivity of Cyanide in Water and Soil. In: Dzombak DA, Ghosh RS, Wong-Chong GM, eds. CYANIDE in WATER and SOIL Chemistry, Risk, and Management. Vol Boca Raton, Fl; 2006:58-88.

17. Wiegand $\mathrm{GH}$, Tremelling $\mathrm{H}$. The kinetics and mechanism of the decomposition of potassium cyanide in aqueous alkaline medium. J Org Chem. 1972;37:914.

18. Mudder T, Whitlock J. Biological Treatment of Cyanidation Wastewaters. Miner Metall Process. 1984:161-165.

19. Miles AM. A Study of the Photocatalytic Effects of Aqueous Suspensions of Platinized Semiconductor Materials on the Reactions Rates of Candidate Redox Reactions. Hampton, Virginia; 1981. doi:LAR-13171.

20. Frank SN, Bard AJ. Heterogeneous Photocatalytic Oxidation of Cyanide Ion in Aqueous Solutions with TiO2 Powder. J Am Chem Soc. 99:303-304. 